VARGA J., HOROTÁN K. \& CSUZDI CS.

\title{
A MESTERSÉGES MEGVILÁGÍTÁS HATÁSA A TALAJFAUNÁRA
}

Eszterházy Károly Egyetem, TTK Biológiai Intézet, Állattani Tanszék, 3300 Eger, Leányka u. 6

\section{Összefoglaló}

A mesterséges fény hatása a repülő állatokra, különösen a rovarokra, Arisztotelész óta jól ismert. Az utóbbi években a fényszennyezéssel kapcsolatosan egyre több tudományterület vizsgálja a jelenséget. Az ALAN (Éjszakai mesterséges fény) hatására vonatkozó ismereteink azonban többnyire a fényre repülő szervezetek fiziológiájára, viselkedésére, szaporodására ragadozó és zsákmány kölcsönkapcsolatainak vizsgálataira korlátozódnak. Ismereteink azonban meglehetősen korlátozottak arra vonatkozóan, hogy az ökoszisztémákban a fénynek van-e hatása a talajban élő állatvilágra. Tanulmányunkban a rendelkezésre álló irodalmak rövid áttekintésével összefoglaljuk az ALAN talajállatokra gyakorolt hatását.

Elfogadva: 2020. 05. 18.

Elektronikusan megjelent: 2020. 


\title{
J. VARGA, K. HOROTÁN \& CS. CSUZDI
}

\section{A MESTERSÉGES MEGVILÁGÍTÁS HATÁSA A TALAJFAUNÁRA}

\author{
Eszterházy Károly Egyetem, TTK Biológiai Intézet, Állattani Tanszék, \\ 3300 Eger, Leányka u. 6 \\ E-mail:varga.janos@uni-eszterhazy.hu
}

\begin{abstract}
The effect of artificial light on flying animals especially insects has been well known and documented since Aristotle and it represents a rapidly growing field of science in recent years. However our current knowledge of the impact of ALAN (Artificial Light At Night) is largely limited to its effects on organismal physiology, behaviour, reproduction and predator-prey interactions. Our knowledge is rather limited on its wider scale effects on the top-down and bottom-up processes of the affected ecosystems and especially on the nonvolant ground dwelling fauna. Here we present a short review of the available literature and summarize the effect of ALAN on the soil animals.
\end{abstract}

Accepted: 18. 05. 2020.

Published online: 2020. 
A mesterséges fényforrásoknak az éjjel repülő állatokat vonzó hatását már igen régen ismerjük, és ezen tulajdonság modern gyakorlati alkalmazása is több mint 150 éves múltra tekint vissza. Az első ilyen szabadalmat az Amerikai Egyesült Államokban 1846-ból jegyzik (Improvement in lanterns for destroying insects. US Patent. 4808, OwENs és mtsai. 2020). A módszert hazánkban először korának neves lepkésze, Abafi-Aigner Lajos használta: az 1800-as évek végén petróleumgőz-lámpával gyűjtött éjszakai lepkéket (HERCZIG 1983).

Már a kezdetleges világító eszközök (fáklya, mécses, gyertya stb.) esetében is megfigyelhető ez a hatás, s ezeket már a rómaiak is felhasználták a méhkaptárak viaszmolyoktól való megvédésére (Beavis 1995), azonban ezeknek a kezdetleges eszközöknek a hatékonysága igen alacsony volt.

Az elektromos izzók térnyerése a XIX. század közepén teljesen átformálta külső és belső épített környezetünk világítás technikáját, és ez a változás (és intenzitásnövekedés) azóta is tart (BRUCE-WHITE, SHARDLow 2011). Az egyre nagyobb területeket érintő éjszakai mesterséges megvilágítás (angolul ALAN - artificial light at night) jelentős hatással van az éjszakai életmódot folytató állatokra is (világszerte a gerincesek mintegy $30 \%$-a, a gerinctelen fajok mintegy $60 \%$ folytat nokturnális életmódot). Az ALAN által kiváltott hatások erősen függenek a fényforrás által kibocsájtott fény spektrumától, valamint intenzitásától; időbeli (pl. cirkadián ritmus, ill. a fotoperiodicitás zavarai) és térbeli tájékozódási zavart, fény-attrakciót (pozitív fototaxis a fényforrás irányába), deszenzitizációt (a fényfelfogó képesség csökkenése, időleges vakság stb.) és alak-, és színfelismerés csökkenését okozhatnak (OWENS \& LEWIs 2018).

Egyre több jel mutat arra, hogy a mesterséges megvilágítás (fényszenynyezés) egyéb tényezők, mint pl. a természetes élőhelyek feldarabolódása, degradációja, a klímaváltozás stb. mellett jelentős szerepet játszhat az utóbbi évtized egyik legégetőbb természeti problémájának a kiváltásában, a rovarok egyedszámának drasztikus csökkenésében (OWENs és mtsai. 2020). Ez a defaunációnak nevezett jelenség az egyes rovarcsoportok esetében akár 45\%-os egyedszám csökkenést is mutathat és alapjaiban befolyásolja a természetes ökoszisztémák működését (DıRzo és mtsai. 2014).

Egyes vizsgálatok alapján a mesterséges fény által bevonzott rovarok mintegy 1/3-a pusztul el még az éjszaka folyamán sérülés, kimerültség vagy predáció nyomán, így az ALAN által okozott rovarpusztulás egy nyár folyamán pl. Németországban elérheti a 100 milliárd egyedet is (EISENBEIS és Hänel 2009). 


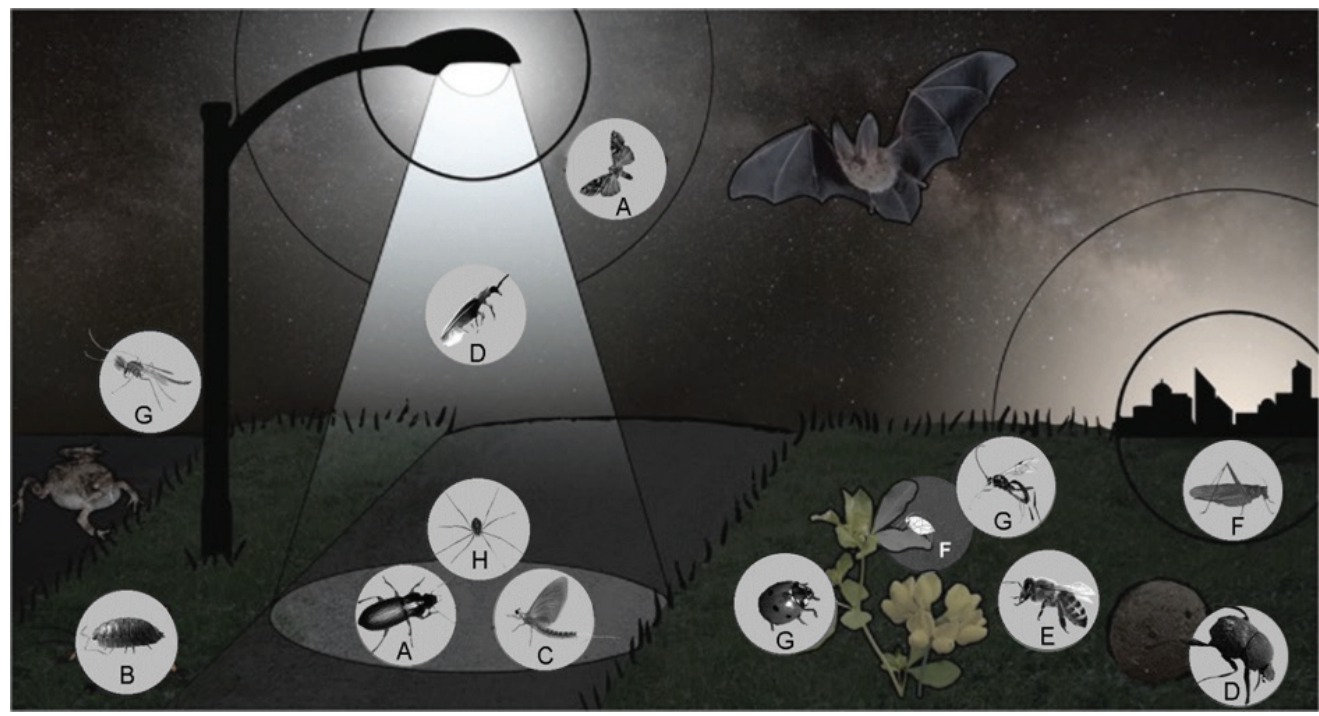

1. Ábra. A mesterséges megvilágítás hatása az állatvilágra. $\mathbf{A}=\mathrm{A}$ fény vonzza az egyes rovarokat pl. éjszakai lepkéket vagy egyes bogarakat. $\mathbf{B}=$ A negatív fototaxist mutató állatok (pl. ászkák) elkerülik a megvilágított területeket. C = A polarizált fényszennyezés a kérészek és más vízirovarok esetében megzavarja a peterakást. $\mathbf{D}=\mathrm{Az}$ ALAN megzavarja a galacsinhajtók tájékozódását és a rovarok biolumineszcens szignálját. $\mathbf{E}=$ Mesterséges megvilágítás hatására felborul a nappali pollinátorok és rovarevők napszakos ritmusa. F = Hosszú távon a fényszennyezés megzavarja a levéltetvet és szöcskék fenológiai ritmusát. G = A fenológiai ritmus felborulása hosszú távon befolyásolja a herbivór-gazdanövény, ragadozó - zsákmány, parazita - gazda kapcsolatot, beporzási sikert és egy tovagyűrűző hatást indukál az ökoszisztémákban. $\mathbf{H}=\mathrm{Az}$ ALAN hatására elhullott bevonzott rovarok hatására megnő a talajfelszínen mozgó ragadozók, dögevők denzitása s ezáltal változik az egész táplálkozási hálózat. (Owens és mtsai. 2020 nyomán, módosítva)

A közvetlen hatás mellett a mesterséges megvilágítás jelentősen befolyásolja egyes rovarok reprodukciós sikerét is. Ismert, hogy a folyamatos fényhatás hím sterilitást és a női szex feromonok csökkenését eredményezi (OwENs et al. 2020). A mesterséges polarizált fényszennyezés pedig a vízirovarok peterakását zavarja meg, így ezek sima, sötét vízfelszínnek tűnő mesterséges felületekre rakják a petéiket (SzÁz és mtsai. 2015).

Mindezek mellett a fényszennyezés befolyásolja a rovarlárvák kifejlődését, az imágók cirkadián ritmusát és a predációs kitettségét is. Így összességében megállapítható, hogy az ALAN kombinálva az élőhelyek csökkenésével, a rovarirtó szerek alkalmazásával, a klímaváltozással jelentős szerepet játszhat a globálisan megfigyelhető rovaregyedszám-csökkenésben (GRUBISIc és mtsai. 2018, OWEns és mtsai. 2020).

Az éjszakai megvilágítás rovarokra, ill. más repülő állatokra (denevérek, madarak stb.) gyakorolt negatív hatása viszonylag jól dokumentált (BRUCE-WHITE és Shardlov 2011, Hölker és mtsai. 2010, Owens és Lewis 2018, Perkin és mtsai. 
2014, Rich és LongCORE 2006), sőt az utóbbi években sikerült kimutatni az állatvilág természetes alkalmazkodását is az ALAN hatásaihoz. AltermatT és EBeRT (2016) kutatásaikban a pókhálós kecskerágómoly (Yponomeuta cagnagella) fototaxisát vizsgálták és kimutatták, hogy az erős fényszennyezésnek kitett élőhelyen nevelkedett populációkból származó lárvákból kifejlődött rovarok 30\%-kal alacsonyabb fényattraktivitást mutattak, mint a "csillagos égbolt" területekről származó példányok. Ez azt mutatja, hogy az urbánus populációk bizonyos mértékben képesek alkalmazkodni, és ezzel csökkenteni az ALAN negatív hatásait.

Az utóbbi években egyre több vizsgálat mutatott rá, hogy a fényszennyezés hatásai jóval összetettebb módon nyilvánulnak meg, és az általa kiváltott felülről jövő (top-down), illetve alulról jövő (bottom-up) folyamatok révén az ALAN jelentősen befolyásolja az érintett területek állatközösségeinek struktúráját, és ezáltal az ökoszisztémák működését.

ALAN hatására a megvilágított területeken megnő a kívülről érkező éjjel aktív rovarok mennyisége. Ennek egy része a talaj felszínére kerülve könnyen elérhető táplálékot kínál a lokális, éjjel aktív ragadozók (pl. pókok, kaszáspókok) számára. Ezzel ellentétben az éjjel megvilágított területeken egyes futóbogarak (Pl. Agonum duftschmidi - széleshátú kisfutó, Carabus granulatus - mezei futrinka, Pterostichus nigrita - sötét gyászfutó) abundanciájának drasztikus csökkenése volt megfigyelhető, feltételezhetően ezen fajok fénykerülő viselkedésének, ill. a megnövekedett pókpopuláció predációs/kompetíciós hatásainak következményeképp. Így a mesterséges megvilágítás hatására a szárazföldre bevonzott vízi eredetü biomassza teljesen átalakította az ALAN hatásának kitett terület táplálékhálózatát (MANFRIN és mtsai. 2017).

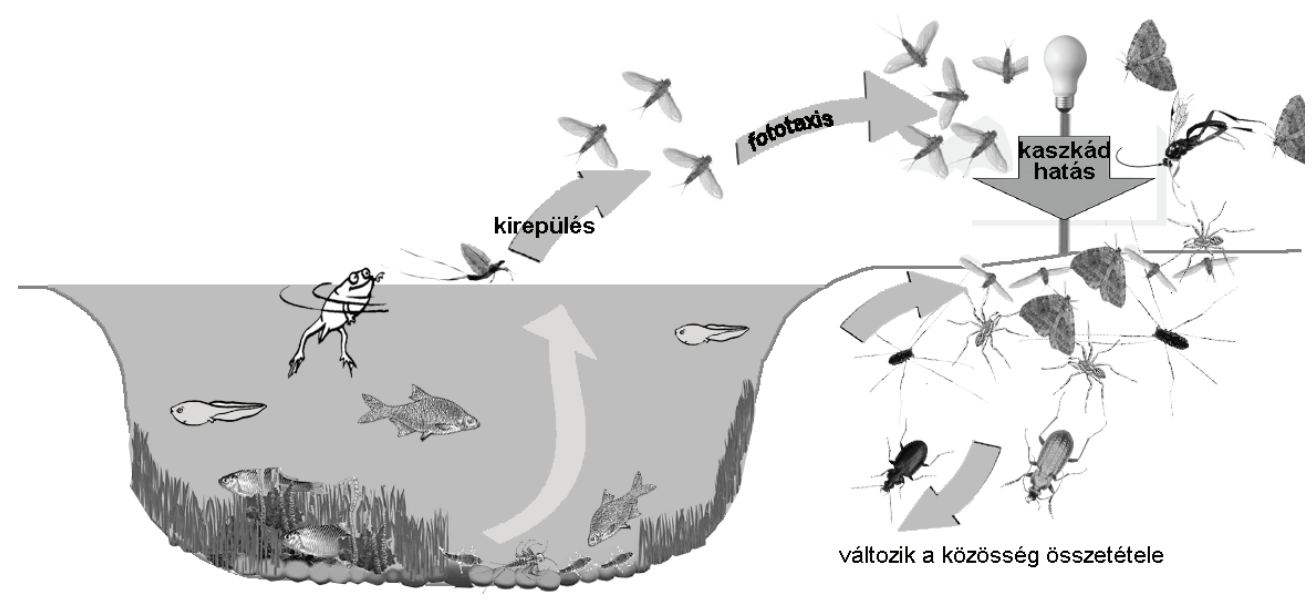

2. Ábra. A mesterséges megvilágítás hatása egy vízparti élőlényközösség összetételére. (Manfrin és mtsai. 2017 nyomán) 
Ez a hatás azonban még csoporton belül is (pl. pókok) erősen faj- (és életmód) függő. Yuen és Bonebrake (2017) egy hálószövő trópusi keresztespók (Nephila pilipes) fogási sikerét vizsgálták egy kísérletben természetes és mesterséges megvilágításnak kitett élőhelyen Hong Kongban. Éjszakánként videomonitorozták a hálók által elfogott lepkéket, és megállapították, hogy az ALAN hatásainak kitett hálók szignifikánsan kevesebb lepkét fogtak, mint a természetes körülmények között szőttek. Feltételezték, egyebek mellett, hogy a megvilágítás hatására a hálók jobban kitűntek a háttérből, és ezáltal a repülő rovarok számára könnyebben felfedezhetőek, ami hozzájárulhatott a megvilágított hálók alacsonyabb fogási sikeréhez.

A mesterséges megvilágítás tovagyűrűző hatásai nem csak a ragadozó-préda kapcsolat esetében okozhat változásokat, de általánosságban befolyásolhatja az állatok cirkadián ritmusát (biológiai óráját). Ez hatással lehet olyan állatokra is (pl. a talajfauna tagjai), melyeket felszín alatti életmódjukból kifolyólag az ALAN hatásainak kevéssé kitettnek gondolhatunk. Ilyen állat pl. az Oniscidea (szárazföldi ászkák) alrendjébe tartozó Tylos spinulosus, egy homokos tengerparton élő szaprofág ászkafaj, melyet DUARTE és mtsai. (2019) vizsgáltak természetes és mesterséges megvilágításnak kitett területen Észak-Chilében. Ez a faj a nappalt a magasabb fekvésű parti régióban tölti homokba beásva, éjjel pedig tömegesen vonul le a vízparti sávba, és a partra vetett algamaradványokkal táplálkozik.

A vizsgálatok eredményei rámutattak, hogy a mesterséges megvilágításnak kitett területen élő állatok elvesztették normális napi ritmusukat, és éjjel is jobbára a homokba beásva maradtak, és az aktivitásukat kismértékben kiterjesztették a nappali órákra is. Ha táplálkoztak, azt a számukra szuboptimális alacsony árapályszintnél tették messze a parttól, ahol jóval kevesebb táplálék állt rendelkezésre.

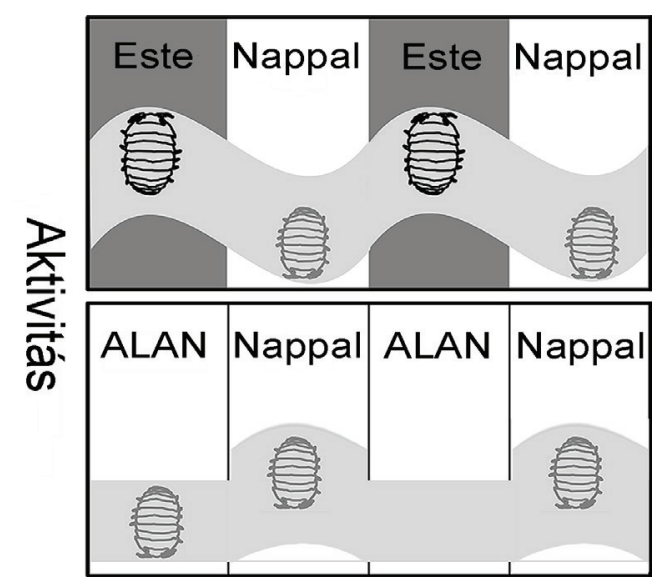

3. Ábra. A mesterséges megvilágítás hatása a Tylos spinulosus ászkafaj cirkadián ritmusára (Duarte és mtsai. 2019 nyomán, módosítva) 
Ennek megfelelően az ászkák abundanciája az ALAN hatásainak kitett területen jóval alacsonyabbnak bizonyult a kontroll területekéhez viszonyítva. A megvilágított területeken egy jól kivehető növekvő egyedsűrűséget mutató trend alakult ki a fényforrástól távolodva. Ezek a kutatások alátámasztották LUARTE és mtsai. (2016) korábbi eredményeit, melyeket az Orchestoidea tuberculata szöcskerák faj kutatása során kaptak.

Igen érdekes eredményeket kaptak Grunsven és mtsai. (2018), melyek egy másik jellegzetesen fénykerülő talajlakó állatcsoportot, a meztelencsigákat vizsgálták egy természetes és mesterségesen megvilágított mezőn. A két mintaterület kb. 600 m-re volt egymástól, és teljesen azonos kezelést kapott (kaszálás, öntözés stb.). A mintavételezés 4 éven keresztül zajlott (2012-2015), és talajba ásott Barber-csapdákkal történt havi egy nap (éjszaka és az azt követő nappal). A kísérleti időszak során 3 meztelencsiga család képviselőit sikerült kimutatni, de egyértelműen a simatestű meztelencsigák (Arionidae) domináltak. A másik két család képviselői (Agriolimacidae, Boettgerillidae) csak elenyésző számban voltak jelen. A vizsgálatok első évében összesen 3, az Agriolimacidae családba tartozó példányt sikerült fogni, de 2013-tól az Agrionidae fajok abundanciája erőteljes emelkedést mutatott a mesterségesen megvilágított területen, amíg a kontroll területen a fogott egyedszámok gyakorlatilag változatlanok maradtak (Fig. 4).

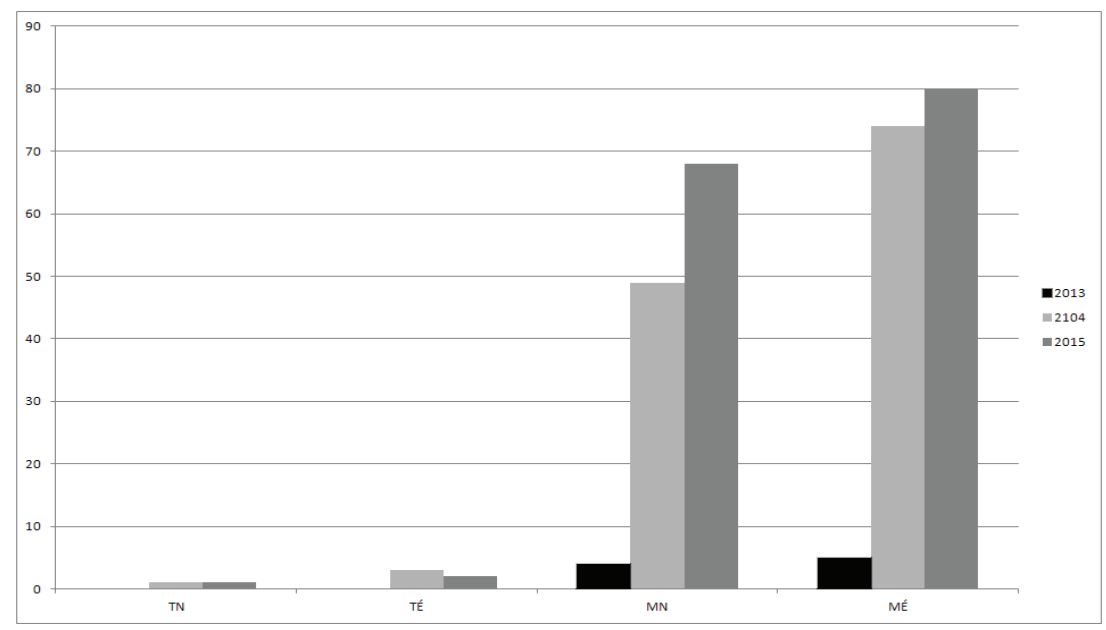

4. Ábra. Az Arion meztelencsigák egyedszámváltozása 2013-2015 között mesterségesen megvilágított és természetes körülmények között. TN = természetes megvilágítás nappal, TÉ = természetes megvilágítás éjszaka, MN = mesterséges megvilágitás nappal, MÉ = mesterséges megvilágírás éjszaka (Grunsven és mtsai. 2018 nyomán módosítva).

Az Arion fajok negatív fototaxisukról ismertek (ZieGer és mtsai. 2009), ezért az egyedszám-növekedésük az ALAN hatásainak kitett területen mindenképp figyelemre méltó. A pontos okokat csak további kutatásokkal lehetne megállapítani, de Grunsven és mtsai. (2018) feltételezték, hogy különböző, felülről 
(top-down) és alulról jövő (bottom-up) hatások együttesen lehetnek felelősek a kapott eredményekért. Ilyen top-down hatás lehet a predáációs nyomás csökkenése a megvilágított területen, mivel ismert, hogy pl. a futóbogarak (a meztelencsigák egyik predátora) denzitása csökken ALAN hatására (MANFRIN és mtsai. 2017). Egy másik lehetséges tényező, hogy a fény hatására odavonzott és elhullott rovarok növelik a talaj nitrogénellátottságát, és ez kombinálva a folyamatos megvilágítással növeli a növényevő meztelencsigák rendelkezésére álló táplálékot mind mennyiségi, mind minőségi értelemben (bottom-up hatás).

Az eddigi legátfogóbb kutatást, amely az ALAN hatását vizsgálta a talaj felszínén mozgó röpképtelen gerinctelen állatcsoportok esetében DAviEs és mtsai (2012) publikálták. Tanulmányukban füves területen Barber-csapdákat használva monitorozták a gerinctelen fauna változását természetes (kontroll), ill. mesterségesen megvilágított területen (nátriumgőz fényforrásnál). A csapdákat 3 napon keresztül ürítették hajnalban és közvetlenül naplemente előtt. Összesen 1194 állatot gyűjtöttek be, melyek 60 talajlakó gerinctelen taxont reprezentáltak. Összességében a megvilágított területeken elhelyezett csapdák szignifikánsan több állatot fogtak, mint a kontroll területen lévők, és ez igaznak bizonyult mind az éjszakai, mind a nappali fogásra. Az egyedszámbeli különbség mellett a két terület fajösszetétele is szignifikánsan különbözött mind nappal, mind éjszaka. Ez arra utal, hogy a megvilágítás hatására tartós strukturális változás alakul ki a fauna összetételében a talajlakó állatok esetében is, még akkor is, ha a növényzet összetételében az ALAN és kontroll terület között nem találtak szignifikáns különbséget. A kaszáspókok, hangyák, holyvák és futóbogarak, ászkák és bolharákok mind magasabb egyedszámmal voltak jelen a megvilágított élőhely foltokban. Ez a különbség a kaszáspókok, hangyák és bogarak esetében mind éjszaka mind nappal megnyilvánult. Bolharákokat és ászkákat azonban csak éjjel sikerült begyűjteni, ezért náluk a napszakos különbségeket nem lehetett tesztelni. Ha az életmód szerinti megosztást nézzük, a megvilágítás hatására a ragadozó és dögevő taxonok egyedszáma nőtt meg leginkább, míg a lebontó és növényevő fajok egyedszáma nem változott jelentősen.
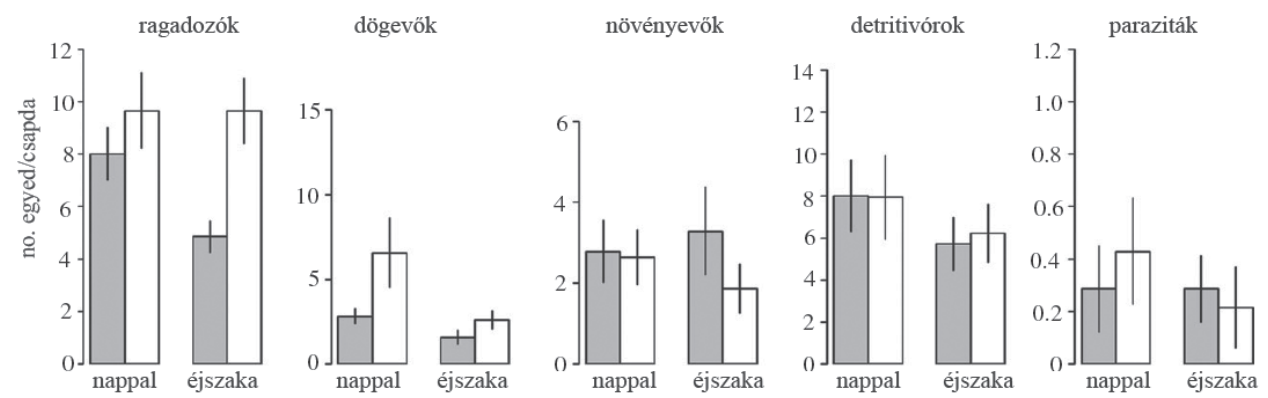

5. Ábra. A megvilágítás hatása különböző táplálkozású gerinctelen taxonokra kontroll (szürke oszlop) és megvilágított (fehér oszlop) területen.

(Davies és mtsai. 2012 nyomán) 
Érdekes kérdést vet fel, hogy vajon egy szigorúan vett talajállat-csoportra, mint pl. a földigiliszták, hogyan hat az éjszakai mesterséges megvilágítás. Nem találtunk olyan irodalmat, ami közvetlenül ezzel a kérdéssel foglalkozna, de NuUtinen és mtsai. (2014) publikációjából érdekes következtetéseket lehet levonni. A szerzők a közönséges földigiliszta (Lumbricus terrestris L., 1758) viselkedését vizsgálták Észak-Finnországban a "fehér éjszakák" időszakában természetes és mesterségesen elsötétített viszonyok között. Az elsötétített kísérletben a giliszták jóval nagyobb aktivitást mutattak, és a sikeres párzások száma is mintegy háromszorosa volt a természetes megvilágításnak kitettekhez képest. Ez arra utalhat, hogy az ALAN erőteljesen befolyásolja a földigiliszták táplálkozási aktivitását és szaporodási sikerét. Az eredmények mélyben aknázó (aneszikus) fajokra vonatkoznak, melyek párzása sötétben a talaj felszínén zajlik, és táplálkozásuk is éjszaka, a talaj felszínéről történik. A mélyebb talajszintekben élő fajok (engogeikus) esetében a hatások feltehetően mások, de ez a téma még további kutatásokat igényel.

\section{Felhasznált irodalom}

Altermatt, F. \& Ebert, D. (2016): Reduced flight-to-light behaviour of moth populations exposed to long-term urban light pollution. Biology Letters, 12: 20160111. DOI: https://doi.org/10.1098/rsbl.2016.0111

BEAvIS, I.C. (1995): The first light trap, 1st century AD. The Entomologist's Record and Journal of Variation, 197:155.

Bruce-White, C. \& Shardlow, M. (2011): A Review of the Impact of Artificiallight on Invertebrates. Buglife - The Invertebrate Conservation Trust, Peterborough, $32 \mathrm{pp}$.

Davies, T.W., Bennie, J. \& Gaston, K.J. (2012): Street lighting changes the composition of invertebrate communities. Biology Letters, 8(5): 764-767. DOI: https://doi. org/10.1098/rsbl.2012.0216

Dirzo, R., Young, H.S., Galetti, M., Ceballos, G., Isaac, N.J.B., \& Collen, B. (2014): Defaunation in the Anthropocene. Science, 345(6195), 401-406. DOI: https:// doi.org/10.1126/science.1251817

Duarte, C., Quintanilla-Ahumada, D., Anguita, C., Manríquez, P. H., Widdicombe, S., Pulgar, J., Silva-Rodriguez, E.A., Cristian, M., Karen, M. \& Quijón, P.A. (2019): Artificial light pollution at night (ALAN) disrupts the distribution and circadian rhythm of a sandy beach isopod. Environmental Pollution, 19: 565-573. DOI: https:// doi.org/10.1016/j.envpol.2019.02.037

EIsENBEIS, G., \& HÄnEL, A. (2009): Light pollution and the impact of artificial night lighting on insects. In. McDonnell, M., Hahs, A. and Brueste, J. (eds.) Ecology of cities and towns: a comparative approach. Cambridge University Press, New York, New York, USA, p. 243-263.

Grubisic, M., van Grunsven, R.H.A., Kyba, C.C.M., Manfrin, A., \& Hölker, F. (2018): Insect declines and agroecosystems: does light pollution matter? Annals of Applied Biology, 173(2):180-189. DOI: https://doi.org/10.1111/aab.12440 
Grunsven van, R.H.A., JÄHNichen, D., Grubisic, M. \& HölkeR, F. (2018): Slugs (Arionidae ) benefit from nocturnal artificial illumination. Journal of Experimental Zoology Part A: Ecological and Integrative Physiology, 329(8-9): 429-433. DOI: https://doi. org/10.1002/jez.2170

HERCIG, B. (1983): Miért repülnek a rovarok a mesterséges fényre? Növényvédelem, 19: 111-118.

Hölker, F., Wolter, C., Perkin, E.K., \& Tockner, K. (2010): Light pollution as a biodiversity threat. Trends in Ecology \& Evolution, 25(12): 681-682. DOI: https://doi. org/10.1016/j.tree.2010.09.007

Luarte, T., Bonta, C.C., Silva-Rodriguez, E.A., Quijón, P.A., Miranda, C., Farias, A.A., DUARTE, C. (2016): Light pollution reduces activity, food consumption and growth rates in a sandy beach invertebrate. Environmental Pollution, 218: 1147e1153. DOI: https://doi.org/10.1016/j.envpol.2016.08.068

Manfrin, A., Singer, G., Larsen, S., Weiss, N., van Grunsven, R. H. A., Weiss, N.-S., Wohlfahrt, S., Monaghan, M. T. \& Hölker, F. (2017): Artificial Light at Night Affects Organism Flux across Ecosystem Boundaries and Drives Community Structure in the Recipient Ecosystem. Frontiers in Environmental Science, 5: 61. DOI: https://doi.org/10.3389/fenvs.2017.00061

NuUtinen, V., Butt, K.R., Jauhiainen, L., Shipitalo, M.J., \& SiRÉn, T. (2014): Dew-worms in white nights: High-latitude light constrains earthworm (Lumbricus terrestris) behaviour at the soil surface. Soil Biology and Biochemistry, 72: 66-74. DOI: https://doi.org/10.1016/j.soilbio.2014.01.023

OWEns, A. C. S., \& LeWIS, S. M. (2018): The impact of artificial light at night on nocturnal insects: A review and synthesis. Ecology and Evolution, 8:1133711358. DOI: https://doi.org/10.1002/ece3.4557

Owens, A.C.S., Cochard, P., Durrant, J., Farnworth, B., Perkin, E.K., \& Seymoure, B. (2020): Light pollution is a driver of insect declines. Biological Conservation, 241:108259. DOI: https://doi.org/10.1016/j.biocon.2019.108259

Perkin, E.K., Hölker, F., \& Tockner, K. (2014): Effects of artificial lighting on adult aquatic and terrestrial insects. Freshwater Biology, 59: 368-377.

Rich, C. \& Longcore T. (2006): Ecological Consequences of Artificial Night Lighting. Island Press, Washington, $479 \mathrm{pp}$.

Száz, D., Horváth, G., Barta, A., Robertson, B.A., Farkas, A., Egri, A., Tarjányı, N., Rácz, G., KRISKA, G. (2015): Lamp-Lit Bridges as Dual Light-Traps for the Night-Swarming Mayfly, Ephoron virgo: Interaction of Polarized and Unpolarized Light Pollution. PLoS One, 10(3):e0121194. DOI: https://doi.org/10.1371/journal.pone.0121194

YUEN, S.W. \& BONEBRAKE, T.C. (2017): Artificial night light alters nocturnal prey interception outcomes for morphologically variable spiders. PeerJ, 5:e4070; DOI: https://doi.org/10.1371/journal.pone.012119410.7717/peerj.4070

Zieger, M.V., Vakoliuk, I.A., Tuchina, O.P., Zhukov, V. \& MeYer-Rochow, V.B. (2009): Eyes and vision in Arion rufus and Deroceras agreste (Mollusca; Gastropoda; Pulmonata): What role does photoreception play in the orientation of these terrestrial slugs? Acta Zoologica, 90(2), 189-204. DOI: https://doi.org/10.1111/j.1463-6395.2008.00369.x 